\title{
The Business of Fashion: A Social History
}

\author{
SARAH JOHNSON \\ Parsons School of Design
}

From Paris to Providence: Fashion, Art, and the Tirocchi Dressmakers' Shop, 1915-1947. Museum of Art, Rhode Island School of Design, Providence, Rhode Island. Susan Hay, curator and project manager. Sarah Buie, exhibition designer. Jan. 12-April 8, 2001. The exhibition website: http://tirocchi.stg.brown.edu/ was developed by Scholarly Technology Group, Brown University.

From Paris to Providence: Fashion, Art, and the Tirocchi Dressmakers' Shop, 1915-1947. Edited by Susan Hay. Providence, R.I. Rhode Island School of Design, 2000. 223 pages. \$29.95 (cloth).

\section{Introduction}

The exhibition, From Paris to Providence: Fashion, Art, and the Tirocchi Dressmakers'Shop, 1915-1947, combined serendipity, archival tenacity, and first-rate scholarship in depicting the production and consumption of high-end women's fashion in the first half of the twentieth century in Providence, Rhode Island. The discovery of the entire contents of a business from the early twentieth century provided an intimate look at the operation of a small American couture design business by immigrant entrepreneurs, Anna Tirocchi and her sister, Laura Tirocchi Cella. From Paris to Providence represented a high

Sarah Johnson is currently serving as the associate chair of the liberal studies department at the Parsons School of Design and is a Ph.D. candidate in historical and critical studies at the University of Brighton, U.K. Her dissertation focuses on women's ready-to-wear clothing in America in the last third of the nineteenth century.

American Quarterly, Vol. 54, No. 3 (September 2002) (C 2002 American Studies Association 


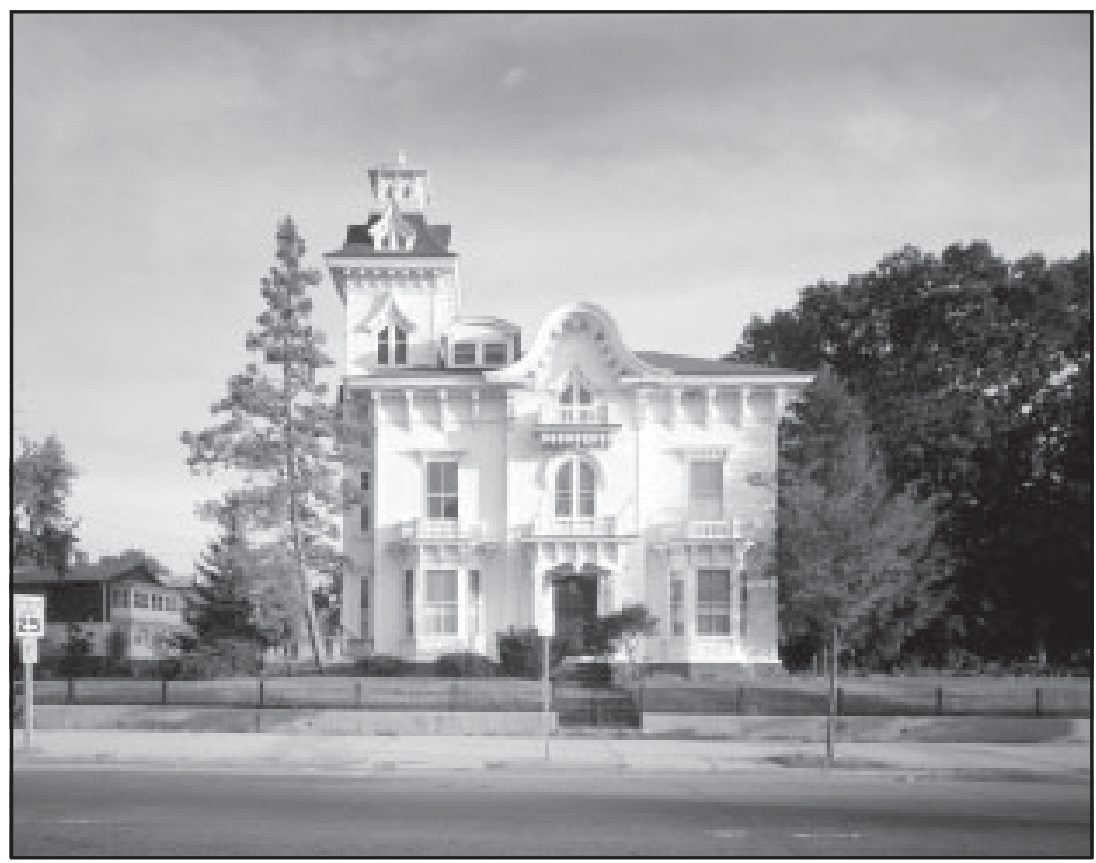

Figure 1. The Prentice Mansion at 514 Broadway, Providence, Rhode Island, the site of the Tirocchi shop and residence from 1915 to 1947; front view, 1999.

standard of interdisciplinary research of interest to scholars of twentieth-century material culture, business history, immigration history, art, costume, and design history, public history and women's studies.

The exhibition, catalog, web site, and programs were the culmination of a twelve-year process guided by Susan Hay, curator of the Department of Costume and Textiles at the Rhode Island School of Design (RISD) Museum. When Anna Tirocchi died in 1947, her sister and business partner Laura Tirocchi Cella placed in storage the contents of the business, including its records, stock of garments, textiles, and accessories, and even the furnishings and equipment that had been used by the business at 514 Broadway in Providence (fig. 1). All this remained untouched until the death of Beatrice, Laura's daughter, who had inherited the property upon Anna's death. In 1990, the property and its contents then passed to Laura's son, Dr. Louis J. Cella, Jr. The unique nature of this collection was recognized by $\mathrm{N}$. David Scotti, a local auctioneer, who acted as the initial intermediary 
between the Cella family and RISD curators and who saved the collection from being sold at auction. After the Cella family agreed to donate the contents of the house and business, Hay and her staff began to catalog all of the objects within the property, a task itself requiring two years' time. ${ }^{1}$

The results of this project, which received multiple grants from the National Endowment for the Humanities along with additional funding from the Rhode Island Committee for the Humanities and the RISD Museum Associates and private support from the Tirocchi-Cella family, offered extraordinary justification for government support of public history projects. Corporate sponsorship, especially for fashion exhibitions, has attracted comment recently because funding has been either directly or indirectly provided by existing firms for displays of their own garments (for example, the fall 2000 Guggenheim Museum's Giorgio Armani exhibition). ${ }^{2}$ Non-commercial funding for the Tirocchi project enabled the long-term research necessary to develop the exhibition over the twelve-year period, without the perception of compromises dictated by corporate funders. Scholarly objectivity for a project of this scale was critical to the exhibition's integrity, spanning from when the site was discovered to the exhibition's opening. Along with the exhibition, the museum offered an array of programs for school children and adults, including lesson plans for visits, and a family guide.

Exhibitions on textiles and dress are necessarily of short duration, given the fragility of the artifacts. However, Hay and her collaborators have done an extraordinary job of ensuring that the project has a lifespan beyond the show's run, thanks to the catalog-with essays by Hay and other costume historians, Pamela Parmel and Madelyn Shaw, and American cultural historians Susan Porter Benson and John W. Briggs - and the project's website. The over three hundred garments and textiles, as well as eighteen cubic feet of archival materials, were donated to the museum collections at RISD and the University of Rhode Island, Kingston. The collections can presently be seen on the internet at http://www.risd.edw/deptsite.cfm?Department=Tirocchi.

An excellent one-day symposium and walking tour, A Day with the Tirocchi Sisters, was held in conjunction with the exhibition on Saturday, March 10, 2001. Essayists from the exhibition catalog, led by Hay and including Susan Porter Benson, John Briggs, and other specialist scholars presented their research to a large, lively crowd, 
addressing the Providence area's local appetite for public history programming. It was gratifying to see such an outpouring of local interest in the Tirocchi sisters' shop, as this was not a conference exclusively for academics. Rather it provided excellent scholarly presentations and a heady discussion involving academics, some Tirocchi family members, and people from the community who brought their reminiscences of clothing consumption, work, and the Italian-American neighborhood of Federal Hill and the Silver Lake area of Providence, where the Tirocchi shop was located. This was public history at its best.

The complete documentation of any historic business is cause for academic celebration, as sites like this one are a rarity. Businesses have long retained records they were legally obliged to keep, but they did not usually do so for the sake of historical interest, unless the material had some promotional value. Business records have also been discarded or destroyed as companies went out of business or were subsumed in more recent corporate mergers. Sometimes funding or staff limitations have prevented materials from being properly archived or stored, or the perception of what scholarly scrutiny will bring is negative. Scholarly access to historical business records is best if the collections have been donated to museums or other archival collections. For example, scholars have mined the Warshaw Collection at the National Museum of American History, Smithsonian Institution, the Winterthur and Hagley Museums, the Wanamaker papers at the Historical Society of Pennsylvania, and the Hartman Center at Duke University, where the materials are properly indexed and stored, and are accessible for scholarly research.

\section{A New Model of Scholarly Interpretation}

The resulting Tirocchi exhibition, catalog, and website represent a significant shift in the museological and scholarly interpretation of the production and consumption of women's garments. The historical study of dress has been inhibited by a major disjuncture in two of the approaches to the subject, an issue broached only in the past fifteen years. The first is the curatorial approach, taken in museums directly addressing the description of objects and their placement within the larger, chronological timeline of style and form. Alternatively, the academic approach seeks to examine clothing as another type of 
consumer object within the historical context of its production, distribution, consumption and potential re-use, and generally does not include the examination of actual garments. ${ }^{3}$ Wendy Gamber's seminal research into the Boston dressmaking and millinery trades stops a bit short of full integration of extant garments and historical context, but her contextual analysis is so refreshing, this awareness is muted by the solidity of her facts. ${ }^{4}$

There are several obvious exceptions where curators have found historical context. Elizabeth Ann Coleman methodically researched and curated the work of three Parisian couturiers in the 1989 Brooklyn Museum exhibition and publication The Opulent Era: Fashions of Worth, Doucet and Pingat. More recently, Alexandra Palmer's Couture and Commerce: The Translantic Fashion Trade in the 1950s "places the couture consumption of elite English-Canadian women in the context of Toronto's postwar culture and society," and aptly fills this void. ${ }^{5}$ Historians have not, however, integrated extant garments into their contextual studies.

As fields of academic inquiry, both consumption and material culture have gained recognition in the last three decades of the twentieth century. Historians studying specific areas of material culture have continued to struggle with limitations imposed by biases ranging from the traditional art historical hierarchies to those subjects subjugated by gender, geography, age, or socio-economic class. Ann Smart Martin proposed three methods of inquiry in the study of clothing consumption, so garments may be accessed in the same ways chairs or buildings have been analyzed: "the way material goods mark or confer position in a social hierarchy; the role of fashion and demand in spurring economic growth and changing manufactures; and the ways in which people can construct their own meanings for objects produced by themselves or others." ${ }^{\prime 6}$ She posited that these methods would lead to the broader contextual analysis of clothing consumption. Martin links the traditional curatorial approach to the analysis of clothing in searching for an interpretive model that will extend the same practices applied to traditionally masculine subjects of historical interpretation.

The Tirocchi exhibition examined the following themes: the Tirocchi sisters' middle-class professional experiences as dressmakers in Italy and after their emigration to Providence; the changing landscape of American dressmaking and retailing industries in the twentieth century; the representative expressions of the major art movements in the styles 
of both two-dimensional (textiles) and three-dimensional (garments and accessories) media. If, as consumption historian Lawrence B. Glickman has written, the best approach to American history is through the lens of material culture, then this exhibition embodies both Martin and Glickman's ideas. Primary and secondary evidence of women's experiences as entrepreneurs, laborers, and clients of high-end custommade and ready-to-wear clothing from 1915 to 1947 was clearly provided by the exhibition. ${ }^{7}$

\section{Exhibition Overview}

The extant garments, textiles, accessories, and sketches provided a jubilant procession into the sartorial world of the early twentieth century. Descriptions of sumptuous living are readily available in the era's fiction. Jay Gatsby's lush parties on Long Island were brought to life by F. Scott Fitzgerald in literature, with flappers dancing the night away in roaring French gowns. Even Ralph Lauren's costumes for the 1970s film version fall flat when compared to the genuine articles. This exhibition captured that indescribable essence, what made the 1920s roar for that limited, upper eschelon, while the rest of America struggled with the inherent inflation so aptly described in Daniel Horowitz's Morality of Spending. Custom-made dresses were made by hand, with a series of fittings on the client, making them distinct from ready-to-wear garments and the one-size-fits-most mentality of mass production. The close fitting garment, combined with cutting-edge French style and extraordinary textiles, created the exclusive type of garment that society women were after when they came to the Tirocchi sisters' shop. The cachet these garments created in cities across America differentiated these women from the less well off, middleclass women who may have had to consume what was locally available, either in a less cosmopolitan dressmaker's shop or at as highend a department store as their purse would allow. They, in turn, would be differentiated from lower-middle-class and working-class women, who may have had to make their own clothing or purchase ready-towear clothing in order to accommodate their entry into the paid workplace. In any event, the socio-economic status represented by a custom-made dress, or an entire wardrobe of these dresses, was what defined the socially elite women of these cities.

The physical space of the exhibition at RISD created both the public face of the shop that clients would have seen as well as the behind-the- 
scenes view of the Tirocchi sisters and their seamstresses' lives. The three-dimensional presentation of the exhibition was successful because it divided the space into sections of the business-the formal showroom, the collection of dresses, textiles, accessories and fashion illustrations, and the workshop. The exhibition design reflected both the production and consumption aspects of the Tirocchi shop.

Concise text panels were clear throughout the gallery spaces and provided historical context for each section of the show. They defined myriad French terms critical to understanding the extant garments and textiles and the modernist art movements to which they were linked. The exhibition did an excellent job of placing the extant garments and textiles into this chronological framework, representing stylistic influences from the modern art movements spawned in Paris and adopted by American clothing firms such as the Tirocchis'.

The garments found in the Tirocchi shop represent various models of production, which changed in the first half of the twentieth century. Most of these garments were custom-made from imported textiles, speaking to the desire of Providence's society women to have exclusive garments representing the most cosmopolitan styles. There are also some examples of high-end ready-to-wear garments in the shop. The styles of these garments would have been chosen by a client from fashion illustrations and then made up at the Tirocchi shop from pre-cut and embroidered panels of textiles to more closely fit the client. Little previous scholarship has documented these pre-packaged "robes" or kits of embroidered textile panels with an illustration for customizable ready-to-wear (fig. 2). ${ }^{8}$ Younger women in the early twentieth century often cast aside the consumption habits of their mothers and grandmothers and opted to buy this sort of high-end ready-to-wear clothing, since fitting was much less time-consuming than going for the series of appointments that a custom-made dress required.

The first room of the exhibition chronicled the Tirocchi family genealogy; they were born in a small town, Guarcino, just south of Rome. As was typical of immigrant families, members of the Tirocchi family came to America throughout the first two decades of the twentieth century and maintained a tight familial network. However, the Tirocchis differed from many southern-Italian immigrants because the family was middle-class. Anna and Laura emigrated as Englishliterate adults in 1905 and probably worked in New York prior to settling in Providence, where other family members had established 


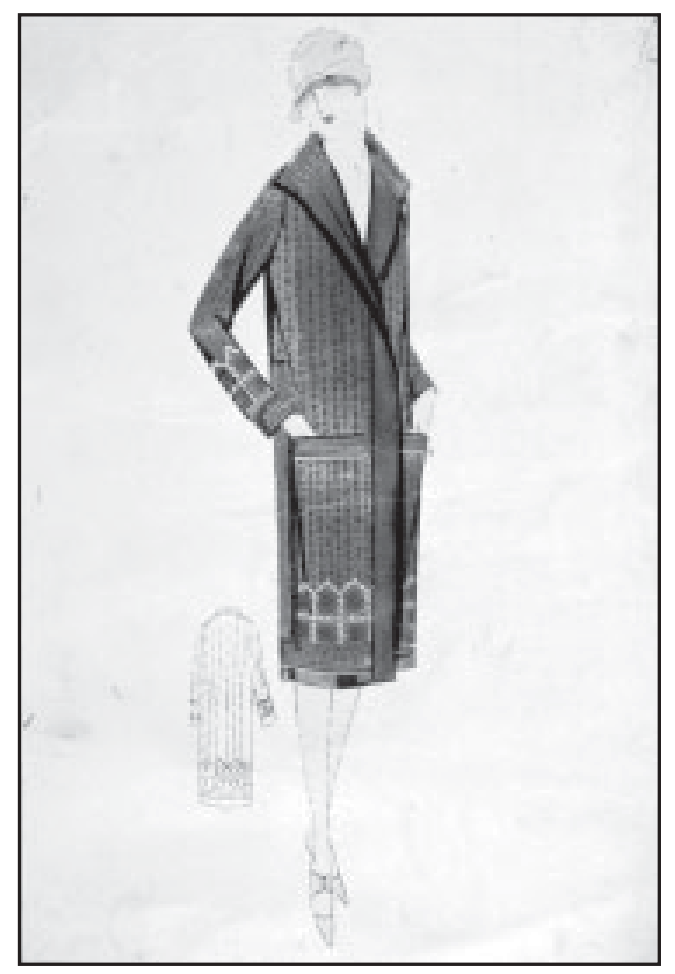

Figure 2. Sketch of a "robe" from the Harry Angelo Company, New York. The collection also features the uncut embroidered textile for the "robe."

themselves. Census research showed the Tirocchi sisters listed as wage-earning tailors in 1910, opening their own business in the Butler Exchange Building in downtown Providence in 1911. In 1915, Anna was able to purchase the large mansion on the West Side of Providence at 514 Broadway, which served as the shop and residence for Anna Tirocchi, her sister Laura, and Laura's husband, Louis J. Cella, an Italian-American physician. ${ }^{9}$

The exhibition at this point segued into a reconstruction of the formal showroom of the Tirocchi Dressmakers' shop where clients would have waited upstairs to be seen for their fittings. This formal reception area was decorated in much the same fashion as a formal Victorian parlor, with ornately carved walnut furniture and display cases for textiles, accessories, and fashion magazines. The fashionable East Side of Providence was home to society's major families, who had 
resided in Providence for several centuries. Quotations taken from oral histories of actual clients or from their present-day family members document the importance of consuming European-inspired couture in Providence society and the sensations caused by wearing a Tirocchi gown to a formal social occasion. For example, Louise Aldrich's 1931 Tirocchi wedding gown was featured photographically and its use was fully documented through archival material and through private family records. Likewise, the photographs and stories of other loyal Tirocchi clients from the East Side of Providence documented the history of the Tirocchi firm and the gradual transition from custom-made to ready-towear clothing at all levels of society.

The Tirocchi collection contains letters written both by clients and by Anna Tirocchi, representing the joys and tensions of such a personal business as custom clothing. Some clients were on friendly terms and regularly exchanged Christmas cards with the sisters. Other correspondence reflects financial constraints, bills past due, and women taking the liberty of canceling a custom order after it had been completed, probably the reason that some of the garments were still in the Tirocchis' possession when the shop closed in 1947.

The social complexity of interactions between middle-class business women and clients representing the highest levels of traditional New England society and the "girls," or young Italian women who worked in the shop, is presented with candor. Rarely is so much known about individual women from all three classes involved in the separate aspects of management, garment production, and high-end consumption. To guard their exclusivity, the Tirocchi sisters had to carefully monitor who they would accept as clients. The only way to maintain a client base of old-guard New England society was to serve those women alone. Additionally, there was social pressure from the top down on the Tirocchi sisters to monitor their interactions with the newer, less affluent Italian-American women in their neighborhood in order to maintain the exclusive status of their custom shop. To its credit, the exhibition focuses on all three social groups without favoring one. The historiography of couture exhibitions has focused on elite clients, with no attempt to provide the context of middle-class shop management, or the working class laborers who made the garments, in part because records regarding the activities of the latter two groups rarely survive. From Paris to Providence represented the socio-economics of both production and consumption in Providence. 
The exhibition mapped out the geography of this local production and consumption from archival data. The Tirocchi clients lived on the wellheeled East Side of Providence, the Tirocchi shop and residence was situated on the then fashionable West Side of Providence, and the shop "girls" lived in the much less affluent Italian-American neighborhoods of Federal Hill and Silver Lake that surrounded the shop's location. An analysis of this geography underscores the fact that the fashionable client was more than just across town, but socio-economically and racially divided from the sewing woman responsible for the construction of her appearance in Providence society.

Initially, the Tirocchi sisters appealed to the upscale society women of Providence because they had been trained in Rome, allegedly by a dressmaker to royalty, and because they were middle-class practitioners with flawless command of the English language. Their story as immigrant women, with complete autonomy in business dealings and intermittent travel to Europe on buying trips, does not reflect the average story of the immigrant women on the Lower East Side of Manhattan, for example, struggling with assimilation issues and family patriarchy, a lack of language facility, and the daily poverty inherent in piece work and sweated labor. The Tirocchi sisters carved out a middleclass existence for themselves and their extended family. By sharing resources and taking business risks, the business survived through horizontal integration in the form of additional property and business acquisitions during the 1910s and 1920s. Archival records suggest that their custom business struggled through the 1930s and held on with a few loyal clients and a limited staff. This struggle for survival in the Depression reflects a larger shift in the garment industry, away from the consumption of custom-made garments in favor of more accessible, less labor-intensive (and therefore less expensive), ready-to-wear garments.

The exhibition also explored correspondence between the Tirocchi shop and its vendors, both in the U.S. and abroad, providing an accounting of the flow of exclusive raw materials required to produce their custom-finished garments. An invoice to A.L. Tirocchi from the French textile firm, Bianchini Férier, dated January 11, 1923 supplied fabric swatches of the French painter Raoul Dufy's textile designs (fig. 3). Combined with employment records, this data may enable future scholars to cost out a garment and compare that cost to its wholesale and retail prices, a method of research rarely applied to historic garment production for lack of extant records. These primary sources 


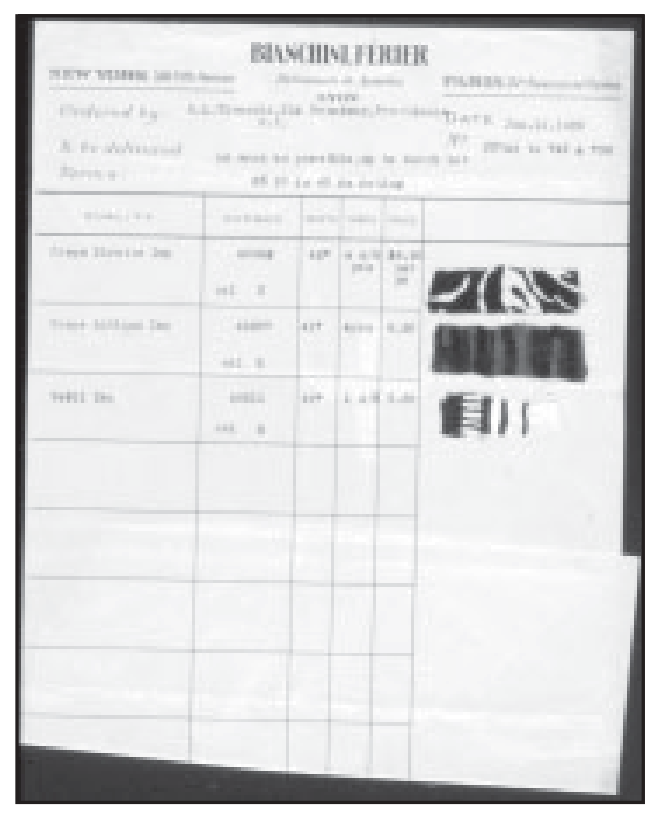

Figure 3. An invoice to A.L. Tirocchi from the French textile firm, Bianchini Férier, dated January 11, 1923. .

suggest how the Tirocchis accommodated preferences for Europeanstyled couture garments by American women of social prominence.

The largest room of the exhibition held a chronological survey of over three hundred garments, textiles, and accessories left in the Tirocchi establishment when it closed in 1947. This gallery examined the relationship of French textile and clothing design to other facets of French modern art and how these styles were transplanted to America via direct importation and fashion journalism. ${ }^{10}$ The clothing and textiles on display not only reflected shifts in taste. They also revealed a great deal about the process of stylistic translation in the shop through redesign and construction. Some extant garments are examples of good design and construction, but others, less successful garments, also survive as design bloopers from the early twentieth century. For example, several gowns of heavier-weight velvets were cut on the bias, or at a forty-five degree angle to the grain. While this produced successful curved seams in lighter-weight fabrics, the results in velvet are a bit less graceful. Examples like these suggest the ups and downs of garment design, as presumably what was left was not found to be 


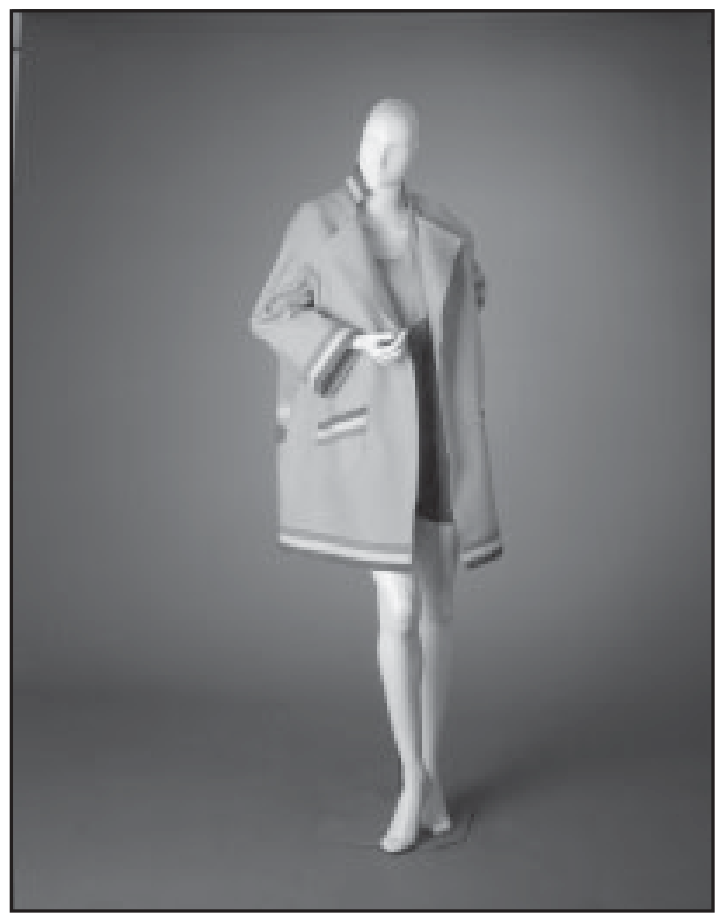

Figure 4. Art Moderne floral beach jacket in wool felt by Tuck-Wite, New York.

satisfactory by the clients for whom the garments were made. Other extant garments represent the less responsible side of consumption and the risk inherent in a custom business. Correspondence revealed that some garments remained at the shop because the client refused to pay for the garment, even if there were no stylistic flaws. The Tirocchis' stock of French accessories, including jewelry, dress ornaments, and handbags also provided more conservative clients with access to the French modernist movements.

This gallery showed how the Tirocchi shop gradually phased out fully custom-made garments for society women, who then adopted luxurious ready-to-wear garments that could be partially altered for a more custom fit. French luxury industries have long been known for their labor-saving efforts, and this exhibition highlights the continuation of an eighteenth-century tradition of custom embroidering panels of textiles in the exact shape and size of the garment's pattern pieces. According to Pamela Parmel these ready-to-wear garments "helped 
dressmakers like Anna survive the radical changes in the fashion industry that occurred after World War I." ${ }^{11}$ Scholarly discussion of these "robes," or pre-packaged production kits to be made up by custom shops during the transitional phase from strict custom-made clothing to ready-to-wear clothing, was significant because very little is known about these high-end customizable, ready-to-wear garments. Their existence has not been common knowledge in the history of clothing, making this exhibition a real contribution to scholarship. Oral history research accompanying the exhibition suggested how the custom industry adapted itself to shifts in production and consumption and used fashion illustrations and packaged styles in lieu of the more creative, collaborative process of designing a dress with input from the dressmaker and client. ${ }^{12}$

Other stylistic shifts are represented by the remnants of the Tirocchi collection. A large inventory of fine lace was found, left behind with the adoption of less frilly, more streamlined garments after World War I. French modernism shifted the stylistic interpretation of forms from the way they appear in nature to starkly abstract shapes, but textile consumption practices suggest that there was a prolonged co-existence of realistic floral patterned textiles with more abstract floral patterns by artists like Raoul Dufy. Garments, textiles, and accessories presented a dazzling chronology of modernist styles in two and three dimensions: abstraction in a pattern-woven silk and wool suit; Cubism-inspired textiles with overprinted patterns; Orientalism in chinoiserie woven and beaded textiles; Art Deco in Machine Age-patterned knits; an Art Moderne floral beach jacket in wool felt by Tuck-Wite, New York (fig. 4); the trompe-l'oeil playfulness of Surrealism in several garments.

\section{Tirocchi Shop "Girls" and the Production of Clothing}

The third room of the exhibition focused on the neighborhood women who came to work at the Tirocchi shop and who collectively produced the garments. Despite scant archival resources, this was perhaps the most interesting room of the exhibition because the workaday realities of clothing production are so often overlooked in scholarly analyses. Employment in the Tirocchi shop provided a matriarchal community for young Italian-American women whose families relied on their wage-earning capabilities. Time books documented the hourly wages and hierarchy of skills intermittently-often 


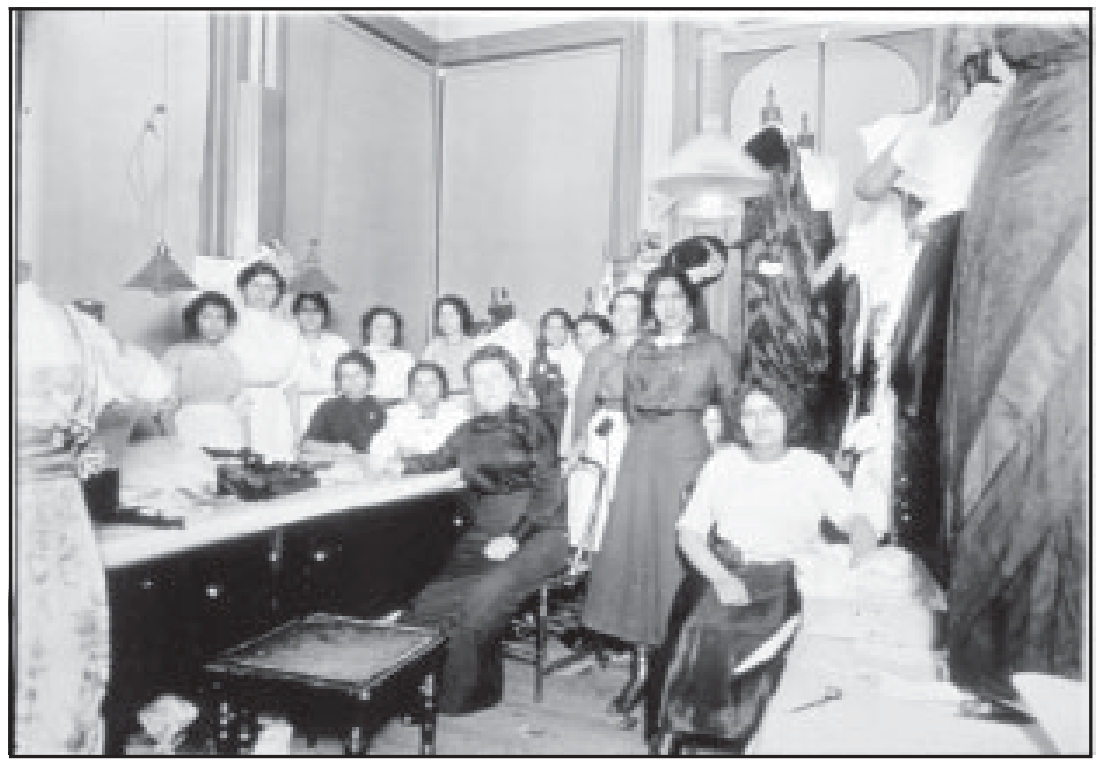

Figure 5. Anna Tirocchi, seated center, and her employees at the Butler Exchange Building shop, c. 1912.

identifying a worker only by her first name — and employment records reflected record-keeping not necessarily in tandem with actual employment practices. Also, the gallery featured several photographs of the workshop spaces. One circa 1912 image of Anna Tirocchi seated among her employees at the Butler Exchange Building shop provided a posed glimpse of daily shop life (fig. 5). The tools of the trade, including storage furniture, sewing machines, notions, and a short chair for pinning hems were also on display.

The Tirrochi sisters did not run a sweatshop or demand homework, but the demands of a custom business called for long, unglamorous hours, probably in violation of Rhode Island's legal maximum work week of fifty-four hours. To counterbalance the ebb and flow of the seasonal custom clothing business, the girls were taken annually to Anna's vacation home in Narragansett. So, while these women were paid lower wages than other women working in larger industries in Providence, the familial ties and "maternalism" of Anna Tirocchi provided them with a safe haven for their years of paid employment. Despite low wages and long hours, many women reminisced with pride 
about the beautiful garments they produced as skilled craftswomen. Perhaps the best example of one worker's story is of Mary Riccitelli Basilico, whose husband Panfilo Basilico provided an oral history of his wife's experiences there. He courted the young Mary while she was one of the core seamstresses and related stories of the family atmosphere and nepotisim in hiring practices at the small shop. When the two married, the shop girls donated labor and the Tirocchis the materials for Mary's wedding gown, equal in quality to those made for clients. ${ }^{13}$

Thus From Paris to Providence interpreted the Tirocchi shop from the perspectives of the three groups of women who knew it: the two entrepreneurial Tirocchi sisters, the wage earners they employed, and the East Side women they served with custom-made clothing. The collections from the shop provide insights into a relatively undocumented era in clothing production, adding to scholarship what has been left untold until relatively recently. Wendy Gamber's seminal work on the Boston dressmaking and millinery trades and Nancy Green's 1997 comparative book on American and French labor in the clothing industries, Ready-to-Wear and Ready-to-Work: A Century of Industry and Immigrants in Paris and New York, are perhaps the most apt comparisons to the Tirocchi research. Also, the Tirocchi sisters' professional experiences, and their adaptation to changes in the American fashion industry, mirror those of other professional women discussed by Angel Kwolek-Folland in Incorporating Women: A History of Women and Business in the United States. ${ }^{14}$

As an exhibition of costume, From Paris to Providence succeeded in breaking free from the art-historical approach of interpreting fashion limited to elite couture and the analysis of the garments as objects d'art. This paradigm, long used by museum curators, clings to the exclusivity of elite consumption and only provides one side of a more vibrant, multi-faceted interpretation of production and consumption. Traditionally, labor history, business history, and consumption history were disparate academic pursuits based upon document-driven primary sources. It was the domain of museum curators to use extant objects from design disciplines to document modern art movements. As From Paris to Providence proves, extant garments, textiles, and accessories provide excellent representation of these chronological, stylistic trends when they are included in historical analyses and fully contextualized with proper research by curators who have been trained as historians. ${ }^{15}$ 
In a limited sense, more progressive history departments have fostered the study of women as producers and consumers of fashionable clothing. The lack of willingness of scholars to accept the ephemerality of fashion as business history or women's production and consumption as legitimate areas of study persists too doggedly in the academic community. It seems untenable that scholars wishing to study this field find themselves to be academic refugees, making the development of this exhibition all the more important to American material culture and costume historiography. Lawrence Glickman's call for the telling of American history through material culture has been vindicated with this fine exhibition, providing the cultural, economic, political, immigration, production and consumption contexts through solidly historical methods of inquiry.

\section{NOTES}

1. Susan Hay, ed., From Paris to Providence: Fashion, Art and the Tirocchi Dressmakers' Shop, 1915-1947 (Providence, R.I.: Rhode Island School of Design Museum of Art, 2000), 14.

2. Eleanor Heartney, "Annals of Sponsorship I: The Guggenheim's New Clothes," Art in America 89 (Feb. 2001): 61-62.

3. Lou Taylor, "Doing the Laundry? A Reassessment of Object-based Dress History," Fashion Theory 2 (1998): 339-44. Christopher Breward, "Cultures, Identities, Histories: Fashioning a Cultural Approach to Dress," Fashion Theory 2 (1998): 301-14, covers a broader, disciplinary scope. Nancy Rexford, Patricia Cunningham, Robert Kaufman, and Patricia Trautman, "Forum: Research and Publication," Dress 14 (1988): 68.

4. Wendy Gamber, The Female Economy: The Millinery and Dressmaking Trades, 1860-1930 (Urbana, Ill.: Univ. of Illinois Press, 1997).

5. Alexandra Palmer, Couture and Commerce: The Translantic Fashion Trade in the 1950s (Vancouver, B.C.: Univ. of British Columbia Press and Royal Ontario Museum, 2001), 8-9.

6. Ann Smart Martin, "Makers, Buyers, and Users: Consumerism as a Material Culture Framework," Winterthur Portfolio 28 (summer/autumn 1993): 142.

7. Lawrence B. Glickman, Consumer Society in American History: A Reader (Ithaca, N.Y.: Cornell Univ. Press, 1999), vii.

8. The existence of such high-end, customizable ready-to-wear garments is especially significant to the history of clothing as it has not generally been acknowledged in scholarship. Ready-to-wear clothing for women is generally interpreted as spreading a more democratic sense of style throughout America in the early twentieth century, though I have contextualized this interpretation as in keeping with American consensus historiography in the 1960s and 1970s in my forthcoming doctoral dissertation. 
9. John W. Briggs, "Strategies for Success: The Tirocchis, Immigration and the Italian American Experience" in Hay, Paris to Providence, 79-86.

10. Susan Hay, "Paris to Providence: French Couture and the Tirocchi Shop" in Hay, Paris to Providence, 133-71. See also Nancy J. Troy, Modernism and the Decorative Arts in France, Art Nouveau to Le Corbusier (New Haven, Conn.: Yale Univ. Press, 1991); and Valerie Steele, Paris Fashion: A Cultural History (New York: Oxford Univ. Press, 1988).

11. Pamela A. Parmal, "Line, Color, Detail, Distinction, Individuality: A. \& L. Tirocchi, Providence Dressmakers" in Hay, Paris to Providence, 37-39.

12. Wendy Gamber, The Female Economy: The Millinery and Dressmaking Trades, 1860-1930, (Urbana, Ill.: Univ. of Illinois Press, 1997), 230.

13. Susan Porter Benson, "Clients and Craftswomen: The Pursuit of Elegance" in Hay, Paris to Providence, 51-76.

14. Angel Kwolek-Folland, Incorporating Women: A History of Women and Business in the United States (New York: Twayne, 1998). See esp. her chapter "Crisis Management: Women and Business at Midcentury, 1930-1963."

15. Paul Greenhalgh, Art Nouveau, 1890-1914 (London and Washington., D.C.: Victoria \& Albert Museum and National Gallery of Art, 2000). This exhibition and catalog were especially remiss in the lack of examples of costume representing the Art Nouveau movement. 